\title{
POLLEN MORPHOLOGY OF THE NATIVE RUTACEAE SPECIES FROM ARGENTINA
}

\author{
Silvina S. Garralla ${ }^{1,2}$ iD \& Lilia R. Mautino ${ }^{1,2}$
}

\begin{abstract}
${ }^{1}$ Centro de Ecología Aplicada del Litoral, Consejo Nacional de Investigaciones Cientificas y Técnicas, Universidad Nacional del Nordeste (CECOAL-CONICET-UNNE), Ruta 5, Km. 2.5, 3400 Corrientes, Corrientes, Argentina; silgabe2@yahoo.com.ar (autor for correspondence).

${ }^{2}$ Departamento de Biología, Facultad de Ciencias Exactas y Naturales y Agrimensura (FACENA), Universidad Nacional del Nordeste (UNNE), Avenida Libertad 5470, 3400 Corrientes, Corrientes, Argentina.
\end{abstract}

\begin{abstract}
Garralla, S. S. \& L. R. Mautino. 2021. Pollen morphology of the native Rutaceae species from Argentina. Darwiniana, nueva serie 9(2): 282-292.

The pollen morphology of 13 native taxa of the Rutaceae from Argentina was studied under optical and scanning electron microscopy to provide new data that would allow delimiting these taxa. The species considered were Balfourodendron riedelianum, Esenbeckia densiflora, E. febrifuga, E grandiflora, Helietta apiculata, Pilocarpus pennatifolius, Zanthoxylum caribaeum, Z. coco, Z. fagara, Z. petiolare, $Z$. rhoifolium, $Z$. riedelianum and Zanthoxylum rigidum ssp. hasslerianum. The general morphological characteristics of the pollen grain of these species are: radiosymmetric, isopolar; small, medium or large size; 3-colporate or 4-colporate; colpus with costa colpi; semitectate (reticulate, striate reticulate or striate). Sculpture, shape and size are the main characters that allow differentiating the studied taxa. Morphological characters among the species are discussed and a species key is presented.
\end{abstract}

Keywords. Argentina; eurypalynous; native species; pollen.

Resumen. Garralla, S. S. \& L. R. Mautino. 2021. Morfología polínica de especies nativas de Rutaceae de Argentina. Darwiniana, nueva serie 9(2): 282-292.

La morfología polínica de 13 especies nativas de Rutaceae de Argentina se estudió bajo microscopio óptico y electrónico de barrido con el fin de aportar nuevos datos que permitan delimitar estos taxones. Las especies consideradas son Balfourodendron riedelianum, Esenbeckia densiflora, E. febrifuga, E. grandiflora, Helietta apiculata, Pilocarpus pennatifolius, Zanthoxylum caribaeum, Z. coco, Z. fagara, $Z$. petiolare, Z. rhoifolium, Z. riedelianum y Z. rigidum ssp. hasslerianum. Los granos de polen de esas especies se caracterizan por ser radiosimétricos, isopolares, de tamaño pequeño, mediano y grande, 3-colporado o 4-colporado, colpos con costillas; semitectado (reticulado, estriado reticulado o estriado). La escultura, forma y tamaño de los granos de polen son los caracteres que permiten diferenciar las especies estudiadas. Se discuten las diferencias de la morfología polínica entre especies y se presenta una clave palinológica para diferenciarlas.

Palabras clave. Argentina; especies nativas; euripolínico; polen.

\section{INTRODUCTION}

The Rutaceae Juss. is an important family of approximately 2040 species, including arboreal and shrub forms or more rarely, herbs or lianas. This family has a cosmopolitan distribution, although best represented in temperate and tropical regions (Morton \& Telmer, 2014). They are well known throughout the world, especially for aromatic species with essential oils and the edible fruits of the Citrus genus (Dutra \& Gasparino, 2018; Groppo et al. 2008; Stevens, 2001). 
In Argentina, the family is distributed in the central and northern regions of the country. It is represented by five native genera included in two tribes: Galipeeae Kallunki: Balfourodendron Corr. Méllo ex Oliv., Esenbeckia Kunth., Helietta Tul. and Pilocarpus Vahl.; Zanthoxyleae Dumont: Zanthoxylum L. (Cole et al., 2020). Thirteen species are found: Balfourodendron riedelianum (Engl.) Engl., Esenbeckia densiflora (Chodat \& Hassl.) Hassl., Esenbeckia febrifuga (A. St. -Hil.) A. Juss ex Mart., Esenbeckia grandiflora Mart., Helietta apiculata Benth., Pilocarpus pennatifolius Lem., Zanthoxylum caribaeum Lam., Zanthoxylum coco Gillies ex Hook. f. \& Arn., Zanthoxylum fagara (L.) Sarg., Zanthoxylum petiolare A. St.-Hil. \& Tul., Zanthoxylum rhoifolium Lam., Zanthoxylum riedelianum Engl. and Zanthoxylum rigidum Humb. \& Bonpl. ex Willd. ssp. hasslerianum (Chodat) Reynel (Flora Argentina, 2020).

The morphology of the pollen grain provides important taxonomic evidence in addition to morphological characters of the plants. In the case of Rutaceae, several studies have examined the pollen morphology of some species treated here and indicated their importance for the taxonomic delimitation of species (Barth, 1980, 1982, 1985; Radaeski et al. 2014; Dutra \& Gasparino, 2018). In South America, several descriptions of some species of Rutaceae have been published by Heusser (1971), Barth (1980, 1982, 1985), Correa et al. (1992), Chase et al. (1999), Grant et al. (2000), Carreira \& Barth (2003), Colinvaux et al. (2005), Magalhães e Silva (2007), Groppo et al. (2010), Radaeski et al. (2014), Feretti \& Mouga (2016) and Dutra \& Gasparino (2018). However, only a few references to native species of Argentina have been provided by Markgraf \& D'Antoni (1978), who illustrate and describe in LM the pollen of Balfourodendron riedelianum and Fagara coco (Grill.) Engl. (synonymous with Zanthoxylum coco Gillies ex Hook, f. \& Arn.). Salgado \& Pire (1998) and Mendez et al. (2016) showed photomicrographs in optical microscopy of pollen grains of Citrus sp. and Zanthoxylum sp., among the species that comprise the pollen composition of the multifloral honey of the Corrientes and Jujuy Provinces, without providing morphological data of these taxa.

The purpose of this study is to analyze in detail the pollen morphology of the native Argentine species of Rutaceae in order to provide new data that allow the delimitation of these taxa.

\section{MATERIALS AND METHODS}

This study of Rutaceae pollen was based on flowers collected from the Corrientes Herbarium (CTES) and details of the examined specimens are given below. The pollen was processed according to Erdtman's method (1960) and mounted in glycerin gelatin. Slides have been deposited in the pollen herbarium of the National University of the Northeast, UNNE (PAL-CTES).

Observations and descriptions of morphological characteristics of the pollen of each species were performed using an Olympus BX40 light microscope (LM) and a Joel JSM-580 scanning electron microscope (SEM). Photomicrographs of the grains in LM were obtained with a Canon Power Shot S50 digital camera. The following parameters were measured under the LM on each sample for a minimum of thirty pollen grains: polar axis, equatorial diameter, thickness of exine (sexine / nexine), length of ectoapertures, width $\mathrm{x}$ height of endoapertures and interapertural area. For a more detailed study of the sculpture of the pollen grains, grains were observed and photomicrographs taken with the SEM at the Secretariat of Science and Technology of the National University of the Northeast (UNNE). For this, acetolysized grains were washed with distilled water, dehydrated in a series of alcohols and metallized with palladium gold. The terminology used in this paper is taken from Nilsson \& Praglowski (1992), Sáenz Laín (2004), Punt et al. (2007), and Hesse et al. (2009).

\section{Specimens examined}

Balfourodendron riedelianum: ARGENTINA. Corrientes. Depto. Ituzaingó, Estancia El Rincón Chico, Tressens et al. 2757 (CTES), PAL-CTES 7503.

Esenbeckia densiflora: PARAGUAY. Depto. Paraguarí. Ypca lac, Soria 2742 (CTES), PALCTES 7509. National Park Ybycuí, Zardini 8751 (CTES), PAL-CTES 7510.

Esenbeckia febrifuga: ARGENTINA. Misiones. Depto. Iguazú, National Park Iguazú, Tressens et al. 4469 (CTES), PAL-CTES 7512. Puerto Iguazú. Keller H. A. et al. 10410 (CTES), PAL-CTES 7247. 
Esenbeckia grandiflora: PARAGUAY. Depto. Amanbay, Schinini \& O. Barrail 31691 (CTES), PAL-CTES 7245. Depto. Canindeyú, Biological reserve Marakajal. Caballero Marmori 1735 (CTES), PAL-CTES 7539.

Helietta apiculata: ARGENTINA. Misiones. Depto. San Ignacio, Club de río. Keller 7681 (CTES), PAL-CTES 7237. Iguazú Department, National Park Iguazú, Placci 239 (CTES), PALCTES 7239.

Pilocarpus pennatifolius: ARGENTINA. Corrientes. Depto. Ituzaingó, Estancia Santa Rita. Tressens et al., 3302 (CTES). PAL-CTES N 7235. Tressens et al., 41153 (CTES). PAL-CTES $\mathrm{N}^{\circ}$ 7236. Rincón del Playadito. Tressens et al. 5048 (CTES), PAL-CTES 7242.

Zanthoxylum caribaeum Lam. ssp. rugosum (A. St.-Hil. \& Tul.): ARGENTINA. Misiones. Depto. Iguazú, National Park Iguazú, Keller \& Gatti 6130 (CTES), PAL-CTES 7246. PARAGUAY. Depto. Itapúa, San Rafael stream, Arbo et al. 2019 (CTES), PAL-CTES 7513.

Zanthoxylum coco: ARGENTINA. Jujuy. Depto. Santa Bárbara, Guagliamone et al. 2593 (CTES), PAL-CTES N ${ }^{\circ}$ 7238. Moradas, Ahumada \& Rotman 4190 (CTES), PAL-CTES 7244.

Zanthoxylum fagara: ARGENTINA. Corrientes. Depto. San Cosme, Route 12, Schinini \& Cristobal 13654 (CTES), PAL-CTES 7221. Depto. Saladas, Krapovikas et al. 45621 (CTES), PAL-CTES 7223.

Córdoba. Depto. Calamuchita, Keller et al. 7511 (CTES), PAL-CTES 7511. PARAGUAY, Depto. Cordillera, Zanja Jhú Hill, Zardini 6252 (CTES), PAL-CTES 7222.

Zanthoxylum petiolare: ARGENTINA. Chaco. Depto. Primero de mayo, Colonia Benitez, Schulz 116888 (CTES), PAL-CTES 7231. Depto. San Fernando, Schinini 13858 (CTES), PAL-CTES 7248. Zanthoxylum rhoifolium: ARGENTINA. Corrientes. Depto. Santo Tomé, Estancia Garruchos, Cabrera 11953 (CTES), PAL-CTES 7232. Depto. San Martín, Schinini et al. 17015 (CTES), PAL-CTES 7240.

Zanthoxylum riedelianum: BRASIL. Campinas. Gehrt 5193 (CTES), PAL-CTES 7233.

Zanthoxylum rigidum ssp. hasslerianum: ARGENTINA. Corrientes. Depto. San Cosme, Route 12. Tressens et al. 1045 (CTES), PAL-CTES 7236. Tressens et al. 1048 (CTES), PAL-CTES 7243.

\section{RESULTS}

\section{General pollen characteristics}

Pollen grains are monads, radiosymetric and isopolar, small, medium to large size, subcircular or circular amb and 3-4 colporate with costa colpi. The thickening of the costa colpi increases progressively from the polar to equatorial region. Ectoapertures with or without a margo and lalongate endoapertures. Exine semitectate, microreticulate, reticulate, striate, striate-reticulate or striatemicroreticulate. Reticulum heterobrochate or homobrochate, muri simplicolumellate in LM. Aperture membranes have granules in SEM. The minimum and maximum measurements of the polar axis $(\mathrm{P})$ and equatorial diameter $(\mathrm{E})$, length of the colpi, width $x$ height of the endoaperture and thickness of exine, sexine/nexine of each species are shown in Table 1.

\section{Genus Balfourodendron}

Balfourodendron riedelianum (Fig. 1 A-D)

Pollen grain subprolate to prolate. Medium size. Amb circular. 3-colporate. The costae colpi increase from $2 \mu \mathrm{m}$ in the polar area to 4-6 $\mu \mathrm{m}$ around the endoaperture. Mesocolpium ca. $10 \mu \mathrm{m}$. Microreticulate exine, microreticulum homobrochate.

SEM: Muri of reticulum of $1-2 \mu \mathrm{m}$ thickness with same nanogranules $<0.4 \mu \mathrm{m}$ (only observable with high magnification; 10,000x). Lumina irregularly shaped and of various sizes, from $0,4 \mu \mathrm{m}$ to $1 \mu \mathrm{m}$ (smaller ones near the ectoapertures). Ectoapertures without margo, aperture membranes with granules $0.8-1.5 \mu \mathrm{m}$ high.

\section{Genus Esenbeckia}

Pollen grains subprolate. Amb circular. Large and medium size. 3-4 colporate. Striate-microreticulate exine. Ectoapertures without margo. Aperture membranes with granules in SEM.

\section{Esenbeckia densiflora (Fig. 1 E-H)}

Pollen grains of medium size. 3-colporate. The costae colpi increase from $2 \mu \mathrm{m}$ in polar area to $4 \mu \mathrm{m}$ around the endoaperture. Mesocolpium ca. $14 \mu \mathrm{m}$. 
Table 1. Comparative measurements (minimum - maximum) in $\mu \mathrm{m}$ of the polar axis $(\mathrm{P})$, equatorial axis $(\mathrm{E})$, length of ectoaperture, width $\mathrm{x}$ height of the endoaperture, thickness of exine, sexine and nexine of pollen grain of the species studied.

\begin{tabular}{lcccccc}
\multicolumn{1}{c}{ Taxa } & $\begin{array}{c}\mathrm{P} \\
(\mu \mathrm{m})\end{array}$ & $\begin{array}{c}\mathrm{E} \\
(\mu \mathrm{m})\end{array}$ & $\begin{array}{c}\text { Ectoaperture } \\
(\mu \mathrm{m})\end{array}$ & $\begin{array}{c}\text { Endoaperture } \\
\text { width } \mathrm{x} \text { height } \\
(\mu \mathrm{m})\end{array}$ & $\begin{array}{c}\text { Exine } \\
(\mu \mathrm{m})\end{array}$ & $\begin{array}{c}\text { Sex } / \text { Nex } \\
(\mu \mathrm{m})\end{array}$ \\
B. riedelianum & $35-51$ & $25-40$ & $28-40$ & $5 \times 3$ & 4 & $2 / 2$ \\
E.densiflora & $28-36$ & $22-28$ & $20-27$ & $3-5 \times 1$ & 2 & $1 / 1$ \\
E. febrifuga & $33-39$ & $25-37$ & $27-37$ & $5-7 \times 1$ & 2 & $1 / 1$ \\
E. grandiflora & $59-70$ & $42-63$ & $39-50$ & $4 \times 2$ & 2 & $1 / 1$ \\
H. apiculata & $31-37$ & $26-27$ & $23-25$ & $3 \times 1$ & 1 & $0.5 / 0.5$ \\
P. pennatifolius & $31-33$ & $17-22$ & $20-23$ & $8 \times 1$ & 2 & $1 / 1$ \\
Z. caribaeum ssp. rugosum & $22-23$ & $20-21$ & $16-18$ & $2 \times 1$ & 2 & $1 / 1$ \\
Z. coco & $22-30$ & $18-21$ & $20-22$ & $2 \times 1$ & 2 & $1 / 1$ \\
Z. fagara & $38-40$ & $36-40$ & $20-27$ & $8 \times 1$ & 2 & $1 / 1$ \\
Z. petiolare & $21-24$ & $18-21$ & $17-20$ & $4 \times 1$ & 22 & $1 / 1$ \\
Z. rhoifolium & $21-23$ & $15-17$ & $17-19$ & $2 \times 1$ & 2 & $1 / 1$ \\
Z. riedelianum & $20-28$ & $16-26$ & $13-20$ & $2 \times 1$ & 2 & $1 / 1$ \\
Z. rigidum ssp. hasslerianum & $25-30$ & $25-17$ & $23-25$ & $7 \times 2$ & 2 & $1 / 1$ \\
\hline
\end{tabular}

SEM: Muri of reticulum of 0.2-0.4 $\mu \mathrm{m}$ thick, densely interwoven. Lumen of 0.2 $0.5 \mu \mathrm{m}$. Grooves narrow and irregular. Aperture membranes with granules ca. $0.5 \mu \mathrm{m}$ high.

\section{Esenbeckia febrifuga (Fig. $1 \mathrm{I}-\mathrm{L}$ )}

Pollen grains of medium size. 3-colporate. The costae colpi increase from $0.5 \mu \mathrm{m}$ in polar area to ca. $2.5 \mu \mathrm{m}$ around the endoaperture. Mesocolpium ca. $24 \mu \mathrm{m}$.

SEM: Muri of ca. $1 \mu \mathrm{m}$ thick, densely interwoven. Lumen of 0.3-0.5 $\mu \mathrm{m}$. Grooves narrow and irregular. Aperture membranes with granules ca. $0.5 \mu \mathrm{m}$ high.

\section{Esenbeckia grandiflora (Fig. 1 M-P)}

Pollen grains of large size. 3-colporate $(40 \%)$ and tetracolporate $(60 \%)$. The costae colpi increase from $1 \mu \mathrm{m}$ in polar area to ca. $7.2 \mu \mathrm{m}$ around the endoaperture. Mesocolpium ca. $27 \mu \mathrm{m}$.

SEM: Muri of reticulum of ca. $0.5 \mu \mathrm{m}$ thick, densely interwoven. Lumen of 0.3-0.5 $\mu \mathrm{m}$. Aperture membranes with granules ca. $0.5 \mu \mathrm{m}$ high.

\section{Genus Helietta}

\section{Helietta apiculata (Fig. 2 A-D)}

Pollen grains subprolate to prolate. Amb circular to subcircular. Medium size. 3-colporate. The costae colpi increase from $0.5 \mu \mathrm{m}$ in polar area to ca. 2-3 $\mu \mathrm{m}$ around the endoaperture. Mesocolpium ca. $10 \mu \mathrm{m}$. Striate exine.

SEM: Muri of ca. 1.5-2.5 $\mu \mathrm{m}$ thick, sometimes branching, generally in the mesocolpia, arranged longitudinally in the direction of the polar axis, but transverse towards the poles. Ectoapertures without margo, aperture membranes with granules ca. $0.5 \mu \mathrm{m}$ high.

\section{Genus Pilocarpus}

\section{Pilocarpus pennatifolius (Fig. 2E-H)}

Pollen grains prolate. Amb circular to subcircular. Small to medium size. 3-colporate. The costae colpi increase from ca. $1 \mu \mathrm{m}$ in polar area to $2 \mu \mathrm{m}$ around the endoaperture. Mesocolpium ca. 7 $\mu \mathrm{m}$. Reticulate exine, reticulum heterobrochate.

SEM: Muri of reticulum of $1.0-1.5 \mu \mathrm{m}$ thick, lumina ca. $0.4-2.5 \mu \mathrm{m}$, decreasing in size towards the ectoapertures and polar area. Some lumina with nanogranules. Ectoapertures without margo, aperture membranes with granules ca. $1.5 \mu \mathrm{m}$ high.

\section{Genus Zanthoxylum}

Pollen grains prolate spheroidal, subprolate or prolate. Amb subcircular or circular. Small and medium size. 3-4 colporate. Exine semitectate and $2 \mu \mathrm{m}$ thick, nexine and sexine $1 \mu \mathrm{m}$ each in LM. 

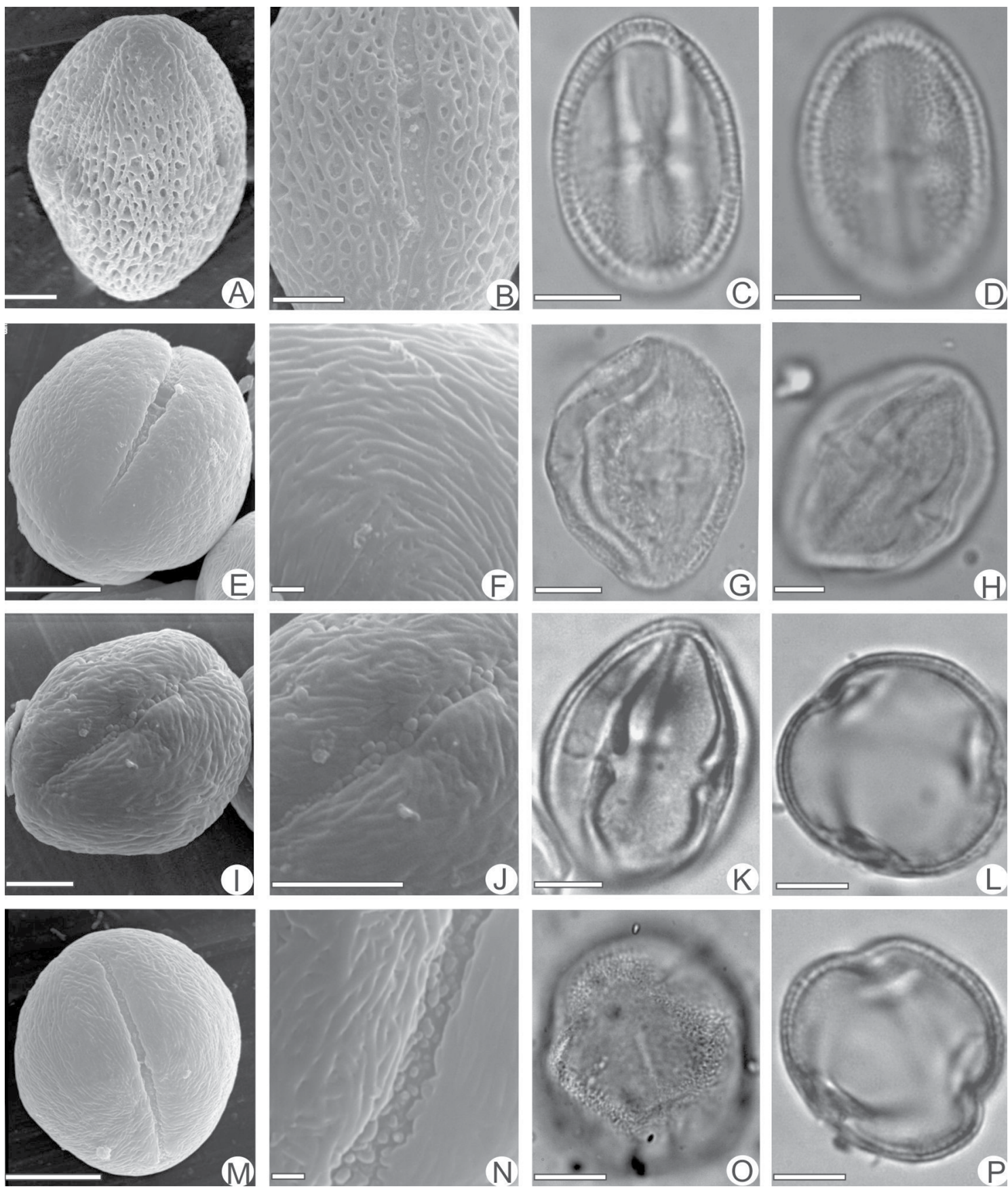

Fig. 1. Balfourodendron riedelianum. A, equatorial view (SEM). B, detail of aperture and exine in equatorial view (SEM). C, cross-section in equatorial view (LM). D, proximal focus in equatorial view (LM). Esenbeckia densiflora. E, general view (SEM). F, detail of sculpture (SEM). G, equatorial view (LM). H, detail of costae colpi in equatorial view (LM). Esenbeckia febrifuga. I, general view (SEM). J, detail of sculpture and apertural membrane (SEM). K, detail of structure and costae colpi in equatorial view (LM). L, cross-section in polar view (LM). Esenbeckia grandiflora. $\mathbf{M}$, equatorial view (SEM). N, detail of sculpture and apertural membrane (SEM). O, detail of structure in polar view, proximal focus. $\mathbf{P}$, cross-section in polar view. The scale equals $1 \mu \mathrm{m}$ in F; $7 \mu \mathrm{m}$ in $\mathrm{G}, \mathrm{H} ; 10 \mu \mathrm{m}$ in $\mathrm{A}, \mathrm{B}, \mathrm{I}, \mathrm{J}, \mathrm{K}, \mathrm{L}, \mathrm{M}$, $\mathrm{N} ; 12 \mu \mathrm{m}$ in $\mathrm{C}, \mathrm{D} ; 11 \mu \mathrm{m}$ in $\mathrm{E}$ and $14 \mu \mathrm{m}$ in $\mathrm{O}, \mathrm{P}$. 

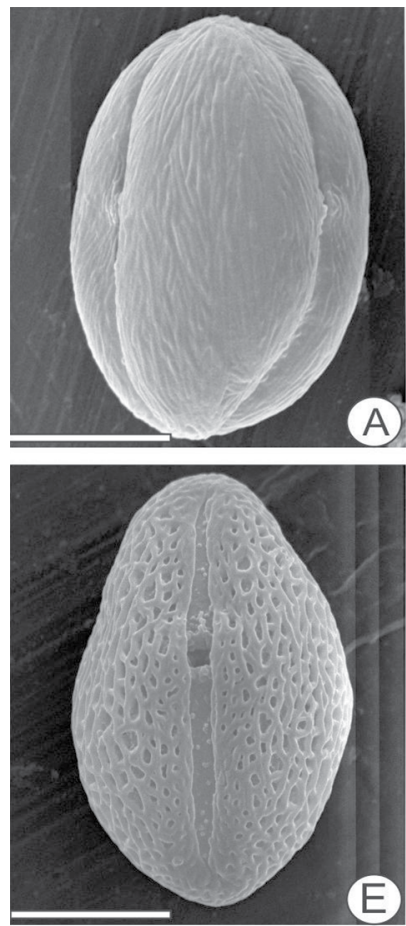

(E)
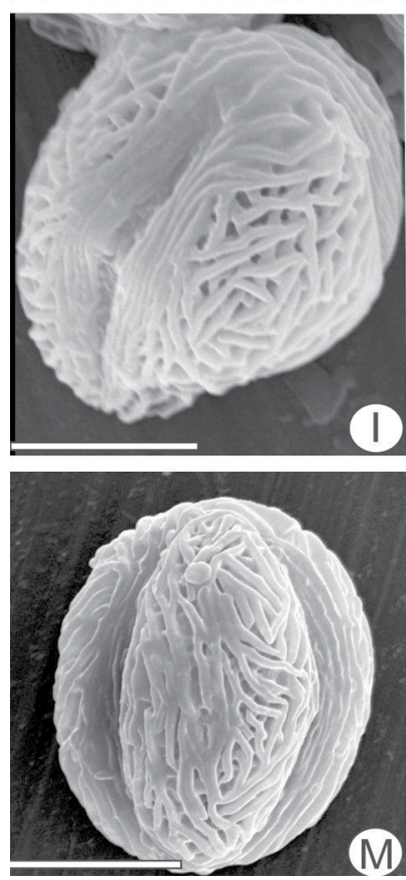

M)
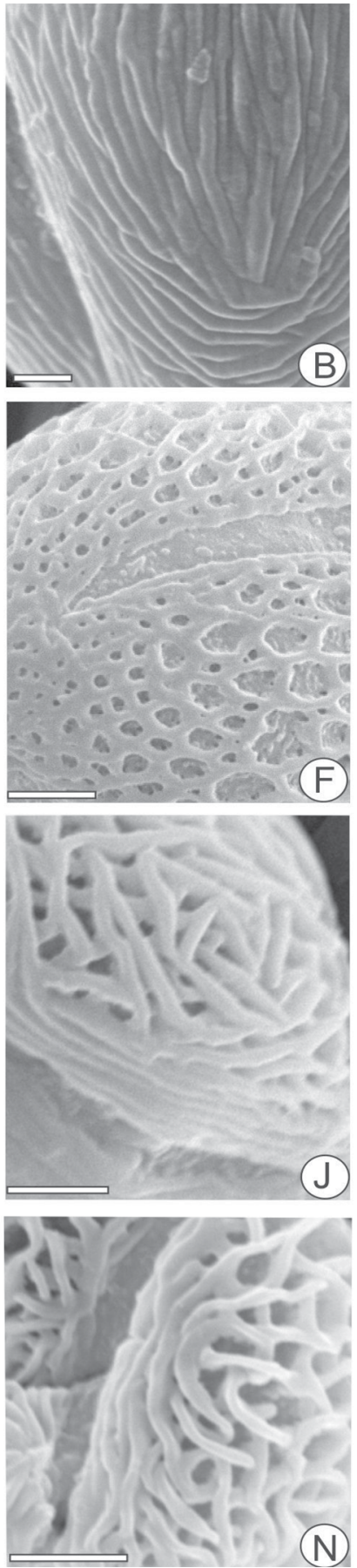
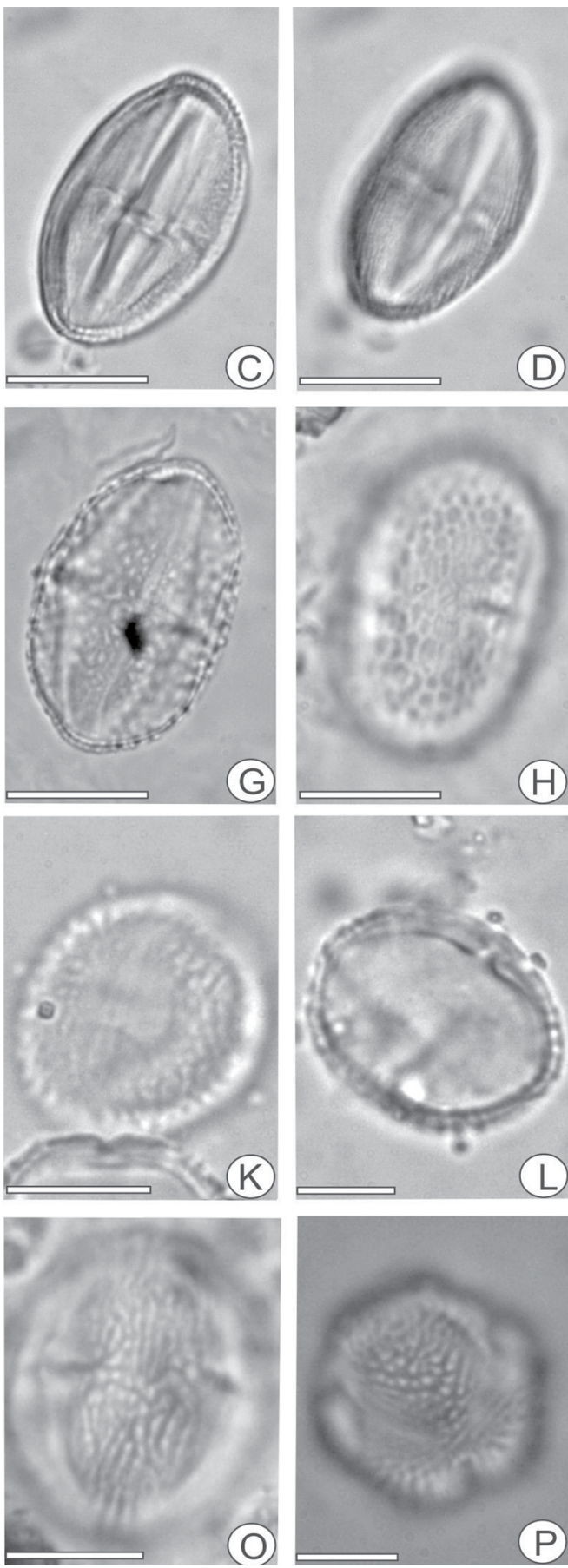

Fig. 2. Helietta apiculata. A, equatorial view. (SEM). B. detail of sculpture (SEM). C. cross-section in equatorial view (LM). D. equatorial view in proximal focus (LM). Pilocarpus pennatifolius. E, equatorial view (SEM). F, detail of sculpture and aperture (SEM). G, cross-section in equatorial view (LM). H, equatorial view in proximal focus (LM). Zanthoxylum caribaeum ssp. rugosum. I, general view (SEM). J, detail of sculture (SEM). K, polar view in proximal focus (LM). L, cross-section in polar (LM). Zanthoxylum coco. M, equatorial view (SEM). N, detail of sculpture and aperture (SEM). O, equatorial view in proximal focus (LM). P, detail in polar view (LM). The scale equals $5 \mu \mathrm{m}$ in $\mathrm{F}$, $\mathrm{B}, \mathrm{J} ; 10 \mu \mathrm{m}$ in I, L, K, M, N, O; $11 \mu \mathrm{m}$ in P; $14,5 \mu \mathrm{m}$ in $\mathrm{A}, \mathrm{D}, \mathrm{E}, \mathrm{G}, \mathrm{H} ; 15 \mu \mathrm{m}$ in $\mathrm{C}$. 
Reticulate or striate-reticulate. Muri of different thickness, lumina irregularly shaped and of various sizes. Ectoapertures with or without margo, aperture membranes with granules in SEM.

\section{Zanthoxylum caribaeum ssp. rugosum}

(Fig. 2 I-L)

Pollen grains prolate spheroidal. Amb subcircular. Small size. 3-colporate. The costae colpi increase from ca. $1 \mu \mathrm{m}$ in polar area to $2.5 \mu \mathrm{m}$ around the endoapertures. Mesocolpium ca. $10.5 \mu \mathrm{m}$. Striate-reticulate exine.

SEM: Muri of reticulum of ca. $0.8 \mu \mathrm{m}$ thick, are arranged in parallel in the ectoapertures regions and reach up to the poles. In the mesocolpium, their arrangement is irregular (reticulum) and the connections between them are at different levels. Lumina irregularly shaped and the size is ca. 0.7-2 $\mu \mathrm{m}$. Ectoapertures with margo, aperture membranes with granules ca. 0.7-0.5 $\mu \mathrm{m}$ high.

\section{Zanthoxylum coco (Fig. 2 M-P)}

Pollen grains subprolate. Amb subcircular and hexagonal. Small to medium size. 3-colporate $(80 \%)$, 4-colporate $(20 \%)$. The costae colpi increase from ca. $1.0 \mu \mathrm{m}$ in polar area to $2.5 \mu \mathrm{m}$ around the endoapertures. Mesocolpium ca. $13.5 \mu \mathrm{m}$. Striate-reticulate exine.

SEM: Muri of reticulum of 1.7-2.0 $\mu \mathrm{m}$ thick, are arranged in parallel along the ectoapertures regions and reach up to the polar area. In the mesocolpium, the connections among the mures are at different levels forming a striate reticulate. Lumina $<1.0-3.5 \mu \mathrm{m}$. Ectoapertures with margo, aperture membranes with granules ca. 0.5-0.7 $\mu \mathrm{m}$ high.

\section{Zanthoxylum fagara (Fig. 3 A-D)}

Pollen grains prolate spheroidal. Amb circular. Medium size. 3-colporate $(90 \%)$, 4-colporate $(10 \%)$. The costae colpi increase from ca. $1 \mu \mathrm{m}$ in the polar area to $2 \mu \mathrm{m}$ around the endoaperture. Mesocolpium ca. $22 \mu \mathrm{m}$. Reticulate exine, reticulum homobrochate.

SEM Muri of reticulum of ca. $1.5 \mu \mathrm{m}$, the connections among them are at different levels. Lumina $<1.0-3.5 \mu \mathrm{m}$. Ectoapertures without margo, aperture membranes with granules ca. $1 \mu \mathrm{m}$ high.

\section{Zanthoxylum petiolare (Fig. $3 \mathrm{E}-\mathrm{H}$ )}

Pollen grains subprolate. Amb circular to subcircular. Small size. 3-colporate. The costae colpi increase from ca. $1 \mu \mathrm{m}$ in polar area to $2.0 \mu \mathrm{m}$ around the endoaperture. Mesocolpium ca. $5 \mu \mathrm{m}$. Reticulate exine, reticulum heterobrochate.

SEM: Muri of reticulum of ca. 0.5-1 $\mu \mathrm{m}$ thick. Lumina ca. $0.5-2 \mu \mathrm{m}$, some lumina with free columellae. Ectoapertures without margo, aperture membranes with granules 1-1.5 $\mu \mathrm{m}$ high.

\section{Zanthoxylum rhoifolium (Fig. 3 I-L)}

Pollen grains prolate. Amb circular to subcircular. Small size. 3-colporate. The costae colpi increase from ca. $1 \mu \mathrm{m}$ in polar area to $2 \mu \mathrm{m}$ around the endoaperture. Mesocolpium ca. $7 \mu \mathrm{m}$. Striate-reticulate exine.

SEM: Muri of reticulum of ca. $1 \mu \mathrm{m}$ thick. Lumina ca. $>1 \mu \mathrm{m}-2.5 \mu \mathrm{m}$. Ectoapertures without margo, aperture membranes with granules ca. 0.5-1 $\mu \mathrm{m}$ high.

\section{Zanthoxylum riedelianum (Fig. $3 \mathrm{M}-\mathrm{P}$ )}

Pollen grains subprolate. Amb circular. Small to medium size. 4-colporate. The costae colpi increase from ca. $1 \mu \mathrm{m}$ in polar area to $2 \mu \mathrm{m}$ around the endoaperture. Mesocolpium ca. $10 \mu \mathrm{m}$. Striate-microreticulate exine.

SEM: Muri of microreticulum of ca. $0.5 \mu \mathrm{m}$ thick. Lumina $>0.5-1 \mu \mathrm{m}$. Some mures are arranged following the direction of the polar axis, forming a striate-microreticulate Ectoapertures without margo, aperture membranes with granules ca. $0.5 \mu \mathrm{m}$ high.

\section{Zanthoxylum rigidum spp. hasslerianum (Fig. 4 A-D)}

Pollen grains subprolate. Amb circular. Small to medium in size. 3-colporate $(80 \%)$, 4 -colporate $(20 \%)$. The costae colpi increase from ca. $1 \mu \mathrm{m}$ in polar area to $2 \mu \mathrm{m}$ around the endoaperture. Mesocolpium ca. $10 \mu \mathrm{m}$. Striatereticulate.

SEM: Muri of reticulum ca. $0.5 \mu \mathrm{m}$ thick, these are arranged following the direction of the polar axis. Lumina ca. 0.5-1.5 $\mu \mathrm{m}$. Ectoapertures with margo, aperture membranes with granules ca. $0.5-1 \mu \mathrm{m}$ high. 

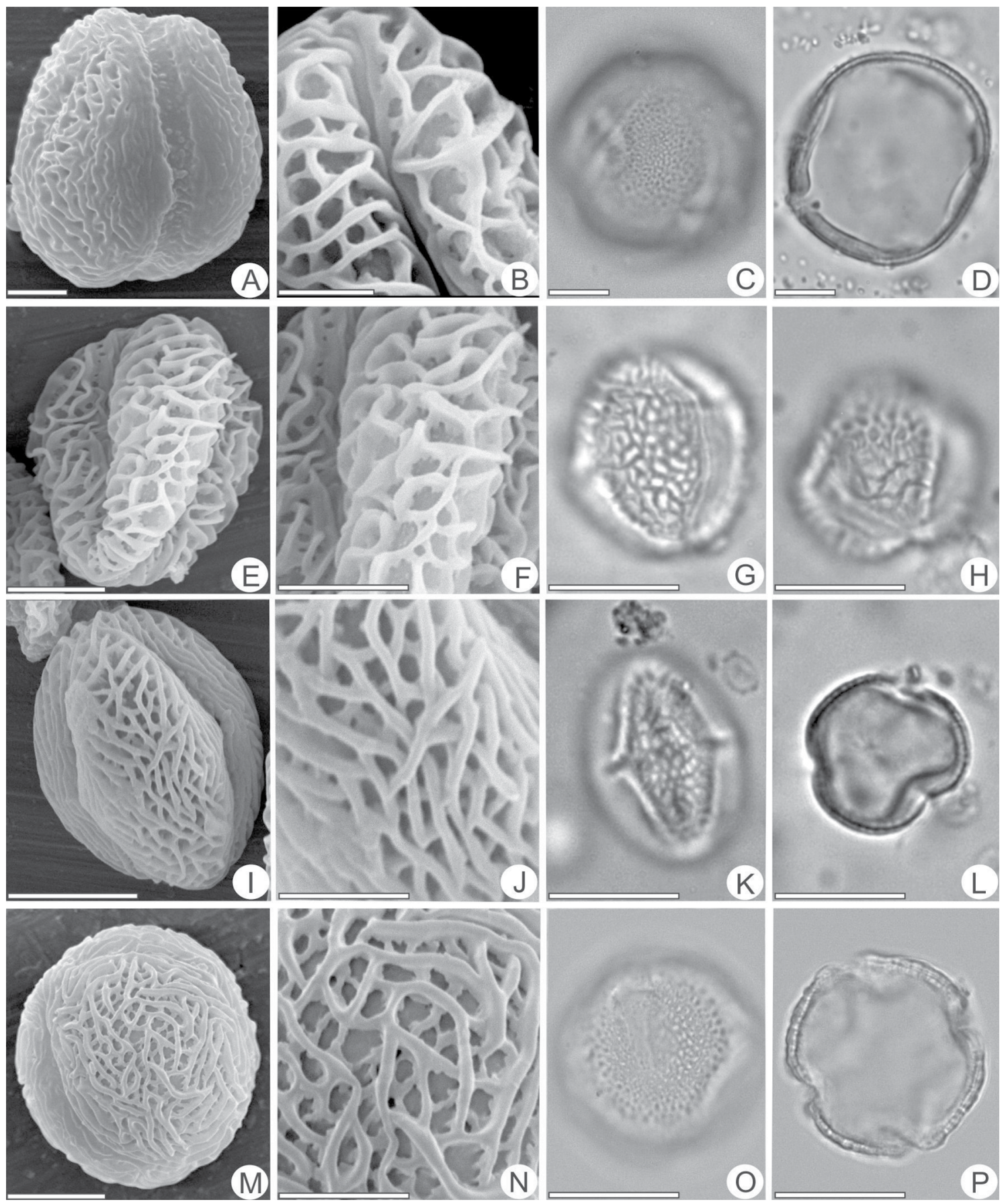

Fig. 3. Zanthoxylum fagara. A, equatorial view (SEM). B, detail of sculpture and aperture (SEM). C, general view in proximal focus (LM). D, cross-section in equatorial view (LM.). Zanthoxylum petiolare. E, equatorial view (SEM). F, detail of sculpture (SEM). G, equatorial view (LM). H, polar view in proximal focus (LM). Zanthoxylum rhoifolium. $\mathbf{I}$, equatorial view (SEM). J, detail of sculpture (SEM). K, equatorial view in proximal focus (LM). L, cross-section in equatorial view (LM). Zanthoxylum riedelianum. M, general view (SEM). N, detail of sculpture and aperture (SEM). $\mathbf{O}$, equatorial view in proximal focus (LM). $\mathbf{P}$, cross-section in equatorial view (LM). The scale equals $5 \mu \mathrm{m}$ in $\mathrm{N} ; 10$ $\mu \mathrm{m}$ in $\mathrm{A}, \mathrm{E}, \mathrm{F}, \mathrm{I}, \mathrm{J}, \mathrm{M}, \mathrm{P} ; 12 \mu \mathrm{m}$ in $\mathrm{B}, \mathrm{G}, \mathrm{K}, \mathrm{D}, \mathrm{H}, \mathrm{L} ; 13 \mu \mathrm{m}$ in $\mathrm{C} ; 17 \mu \mathrm{m}$ in $\mathrm{O}$. 

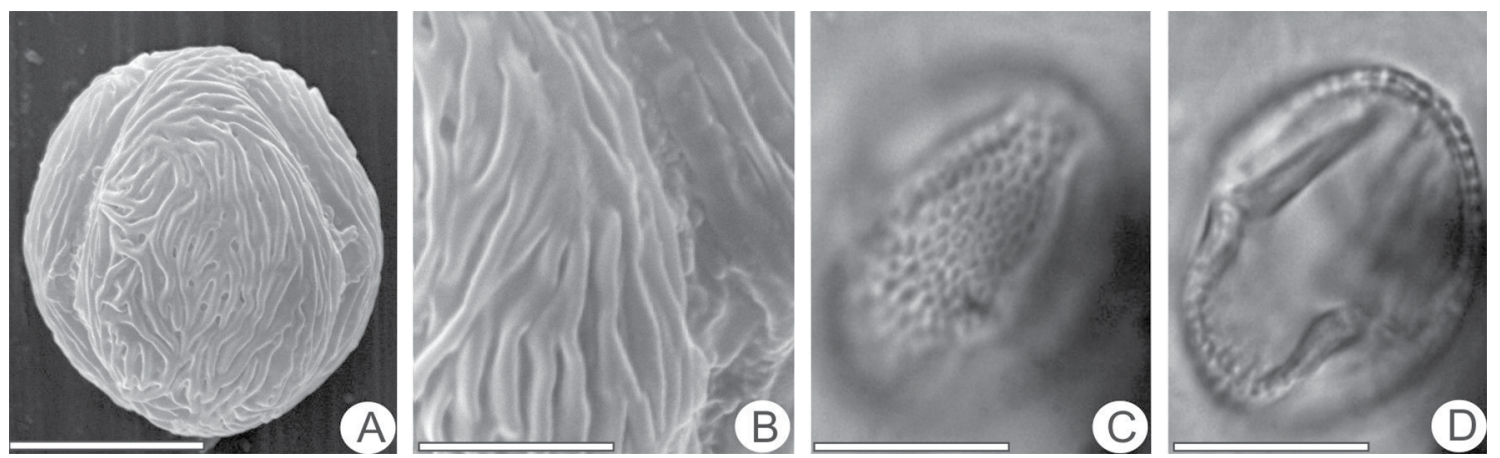

Fig. 4. Zanthoxylum rigidum spp. haslerianum. A, general view (SEM). B, detail of sculpture and aperture (SEM). C, proximal focus in equatorial view (LM). D, cross-section in equatorial view (LM.). The scale equals $5 \mu \mathrm{m}$ in B; $14 \mu \mathrm{m}$ in $\mathrm{A}, \mathrm{C}, \mathrm{D}$.

\section{Pollen key of native Argentinean Rutaceae species}

1. Pollen grain microreticulate or reticulate 2

1. Pollen grain striate, striate-reticulate or striate-microrreticulate 5

2(1). Exine microreticulate Balfourodendron riedelianum

2. Exine reticulate Pilocarpus pennatifolius

(2). Prolate pollen grain

3. Subprolate or prolate spheroidal pollen grain

4(3). Subprolate pollen grain

Zanthoxylum petiolare

4. Prolate spheroidal pollen grain Zanthoxylum fagara

5(1). Striate pollen grain Helietta apiculata

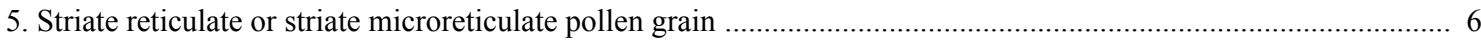

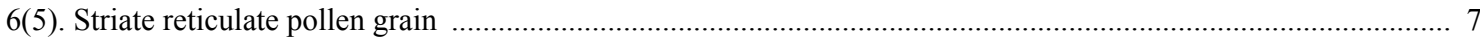

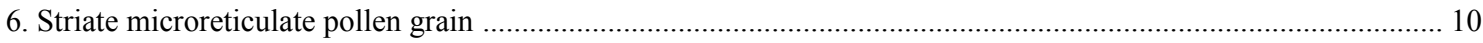

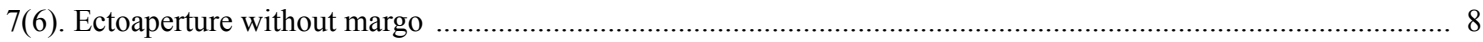

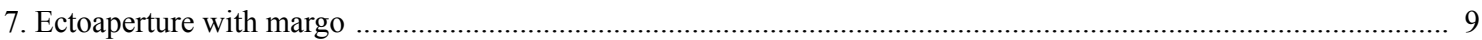

8(7). Prolate pollen grain

Zanthoxylum rhoifolium

8. Subprolate pollen grain Zanthoxylum rigidum ssp. hasslerianum

9(7). Prolate spheroidal pollen grain

9. Subprolate pollen grain Zanthoxylum caribaeum ssp. rugosum 10(6). With lumina $<0.5 \mu \mathrm{m}$ Zanthoxylum coco 10.With lumina of $0.5-1 \mu \mathrm{m}$ 11(10). Large size pollen grain Zanthoxylum riedelianum 11. Medium size pollen grain Esenbeckia grandiflora Esenbeckia densiflora, Esenbeckia febrifuga

\section{DISCUSSION AND CONCLUSIONS}

Rutaceae is a eurypalynous family where the characters corresponding to sculpture of the pollen grains, and the shape, size and ectoapertures with or without margo are the most important diagnostic elements that can be used for the identification of the native Argentine species. These characters allowed us to prepare the pollen key. On the other hand, symmetry, polarity, structure of the exine, and amb and apertures 3-4 colporate with lalongate endoapertures are characters that appear very similar in all species. Although all species have pollen grains with semitectate exine, these can be grouped among those with microreticulate or reticulate exine (Balfourodendron riedelianum, Pilocarpus pennatifolius, Zanthoxylum fagara, Zanthoxylum petiolare) and those with striated, striate reticulate or striate microreticulate exine (Helietta apiculate, Zanthoxylum rhoifolium, Zanthoxylum coco, 
Zanthoxylum rigidum spp. hasslerianum, Zanthoxylum caribaeum ssp. rugosum, Zanthoxylum riedelianum, Esenbeckia grandiflora, Esenbeckia densiflora, Esenbeckia febrifuga).

The pollen grains with microreticulate and reticulate exine show variation in the arrangement of reticulum and can be separated between those that present an evident reduction of the lumina size toward the ectoapertures margins (Balfourodendron riedelianum, Pilocarpus pennatifolius) and those that do not present a reduction (Zanthoxylum petiolare, Zanthoxylum fagara). On the other hand, pollen grains with reticulate exine can be differentiated by their shape into prolate, subprolate or prolate-spheroidal.

Balfourodendron riedelianum, with a microreticulate exine, has characters concordant (small to medium size, subprolate, 3-colporate, with margo, lalongate endoapertures, microreticulate homobrochate exine) with those published by Dutra \& Gasparino (2018) for species in Brazil. However, Barth (1982) points out that this species is smaller in size, with a psilate exine in LM and is finely undulated and striated in SEM.

Barth (1985) published a detailed study of pollen grains of nine Brazilian species of Pilocarpus. Among the species of this genus, Pilocarpus pennatifolius is the only one also found in Argentina and our results are similar to those from Brazilian species.

Species whose pollen grains have striate, striatereticulate or striate-microreticulated exine can be differentiated by the sculpture of the exine, lumen, shape and size. In species with striate or reticulate pollen grains (Zanthoxylum rhoifolium, Zanthoxylum rigidum ssp. hasslerianum, Zanthoxylum caribaeum ssp. rugosum, Zanthoxylum coco) the presence of ectoaperture with or without a margo and the shape are the characters that allow them to be differentiated from each other. On the other hand, Esenbeckia densiflora cannot be differentiated from Esenbeckia febrifuga by the morphological pollen characters.

Radaeski et al. (2014) describes pollen grains of Helietta apiculata from Brazil with a striatemicroreticulate exine under LM and SEM. The other characteristics are agreement with the ones analysed here.

Pollen grains of Zanthoxylum petiolare (synonym of Fagara naranjillo (Griseb.) Engl.), Zanthoxylum rhoifolium, Zanthoxylum rigidum ssp. hasslerianum (synonym of Fagara hassleriana Chodat) and Zanthoxylum riedelianum were described in Barth's (1980) descriptions of the Brazilian species of Zanthoxylum. Although generally their morphological descriptions are similar to the same species from Argentina, some differences were identified, perhaps because previous studies were based on only the light microscope. Barth (1982) analyzed the pollen characteristics of the genera Zanthoxylum, Pilocarpus, Esenbeckia and Helietta pointing out that they present the basic type: 3-colporate, reticulate and striate.

The pollen of Zanthoxylum petiolare was described in Dutra \& Gasparino (2018) as striate-reticulate exine with reticula homobrochate in mesocolpium and apocolpium striate-reticulate, whereas our results indicate they are reticulate heterobrochate.

The pollen morphology of Baulfourodendron riedelianum, Esenbeckia febrifuga, Helietta apiculata, Zanthoxylum caribaeum, Zanthoxylum petiolari, Zanthoxylum rhoifolium and Zanthoxylum riedelianum was also analyzed by Dutra \& Gasparino (2018) from species from São Paulo, Brazil. Comparing their results with those analyzed here, slight differences are observed in the overall shape of the pollen grains and can be attributed to variations in pollen within the genus or species.

According to the phylogeny of the Rutaceae of Argentina (Cole et al., 2020), the genera of the tribe Galipeeae, subtribe Pilocarpinae (Pilocarpus, Balfourodendron, Esenbeckia and Helietta) are characterized by having prolate or subprolate pollen grains, with reticulate, microreticulate, striatemicroreticulate or striate exine, ectoapertures without a margo. Although Zanthoxylum (a more phylogenetically distant genus) is included in the tribe Zanthoxyleae, it has palynological characters (spheroidal prolate, subprolate or prolate with reticulated or reticulated striated exine and ectoaperture with or without margo) that overlap with the tribe Galipeeae, subtribe Pilocarpinae. The phylogenetically closest genera that belong to the same clade (Helietta, Esenbeckia and Balfourodendron) share the pollen characters of subprolate, without margo.

Finally, the pollen grain of native species of Rutaceae from Argentina have semitectate exine with reticulate, microreticulate, striate or striate microreticulate surface, ectoaperture with or without margo and endoapertures with costa endocolpi. 


\section{ACKNOWLEDGEMENTS}

The authors thank to Centro de Ecología Aplicada del Litoral (CECOAL-CONICET-UNNE) for providing us with the facilities to carry out this study, to the Instituto de Botánica del Nordeste (IBONE) for permission to take pollen samples from their herbarium sheets, to Dr. Konrrad Gajewsky for valuable comments on the manuscript and Yanina Horn for technical assistance. This work was financially supported by the National University of the Northeast (UNNE) Argentine.

\section{BIBLIOGRAPHY}

Barth, O. M. 1980. Pollen morphology of a Brazilian Rutaceae. Zanthoxylum (Fagara). Pollen et Spores 22 (3-4): 425-436.

Barth, O. M. 1982. Variaçiônes polínicas em especies brasileiras da família Rutaceae. Boletim del Instituto de Geociencias USP 13: 129-134.

Barth, O. M. 1985. Pollen morphology of Brazilian Rutaceae: Pilocarpus. Pollen et Spores 27 (2): 145-153.

Carreira, L. M. M. \& O. M. Barth. 2003. Atlas de pólen da vegetação de canga da Serra de Carajás, Pará, Brasil. Belém: Museu Paraense Emilio Goeldi; 112 p.

Chase, M. W.; C. M. Morton \& J. A. Kallunki. 1999. Phylogenetic Relationships of Rutaceae: A Cladistic Analysis of the Subfamilies Using Evidence from rbcL and atpB Sequence Variation. American Journal of Botany 86 (8): 1191-1199. DOI: http://doi.org/10.2307/2656983

Cole, T. C. H.; M. Groppo \& A. González. 2020. Filogenia de las Rutaceae. Poster en español. Freie Universitât Berlin.

Colinvaux, P.; P. E. De Olivera \& J. E. Moreno Patiño. 2005. Amazon Pollen Manual and Atlas. Harwood Academic Publishers. $413 \mathrm{p}$.

Correa, A. M. S.; H. M. Watanabe \& T. S. Melhem. 1992. Flora Polínica da Reserva do Parque Estadual das Fontes do Ipiranga (São Paulo, Brasil). Hoehnea 19:117-124.

Dutra, F. V. \& E. C. Gasparino. 2018. Pollen morphology of Rutaceae from Brazilian forest fragments. Palynology 42 (1):4354. DOI: http://doi.org/10.1080/01916122.2017.1306812

Erdtman G. 1960. The acetolysis method. A revised description. Svensk Botanisk Tidskrift 54: 561-564.

Feretti, V. \& D. M. D. Mouga. 2016. Pollinic characterization of species of the botanic family Rutaceae Juss. Acta Biológica Catarinense 3 (1): 5-11.

Flora Argentina. 2020. Flora Argentina: Plantas Vasculares de la República Argentina. Published on the Internet: http:// www.floraargentina.edu.ar [Accessed April 2020].
Grant,M.;S.Blackmore\&C.M.Morton.2000.Pollenmorphology of the subfamily Aurantioideae (Rutaceae). Grana 39: 8-20. DOI: http://doi.org/10.1080/00173130150503768

Groppo, M.; J. R. Pirani, M. L. F. Salatino, S. R. Blanco \& J. A. Kallunki. 2008. Phylogeny or Rutaceae based on two noncoding regions from CP DAN. American Journal of Botany 95(8): 985-1005. DOI: http://doi.org/10.3732/ajb.2007313

Groppo, M.; M. A. V. da Cruz-Barros \& A. da Silva Correa. 2010. Pollen morphology of species of Hortia (Rutaceae). Revista Brasileira de Botânica 33 (1): 13-20. DOI: https:// doi.org/10.1590/S0100-84042010000100003

Hesse, M.; H. Halbritter, R. Zetter, M. Weber, R. Buchner, A. Frosch-Radivo \&S. Ulrich. 2009. Pollen Terminology An illustrated handbook. Ed. Pringerien New York Pollen Springer-Verlag/Wien, Austria. 266p.

Heusser, C. J. 1971. Pollen and Spores of Chile. Modern Types of Pteridophyta, Gymnospermae and Angiospermae. The University of Arizona Press. Tucson.

Magalhães e Silva, F. H. 2007. Contribuições à Palinologia das Caatingas. PhD Thesis. Feira de Santana: State University of Feira de Santana. 182 p.

Markgraf, V. \& H. D'Antoni, 1978. Pollen Flora of Argentina. Modern Spore and Pollen Types of Pteridophyta, Gymnospermae and Angiospermae. The University of Arizona Press. Tucson.

Méndez, M. V.; A. C. Sanchez, F. F. Flores \& L.C. Lupo. 2016. Análisis polínico de mieles inmaduras en el sector oeste de las Yungas de Jujuy (Argentina). Boletín de la Sociedad Argentina de Botánica 51(3): 449-462. DOI: http://doi. org/10.31055/1851.2372.v51.n3.15390

Morton, C. M. \& C. Telmer. 2014. New Subfamily classification for the Rutaceae. Annals of the Missouri Botanical Garden 99 (4): 620-641.

Nilsson, S. \& J. Praglowski. 1992. Erdtman's Handbook of Palynology. 2da. ed. Munksgaard, Copenhagen. 582p.

Punt, W.; P. P. Hoen, S. Blackmore, S. Nilsson \& A. Le Thomas. 2007. Glossary of pollen and spore terminology. Review of Palaeobotany and Palynology 143: 1-81. DOI: https://doi. org/10.1016/j.revpalbo.2006.06.008

Radaeski, J. N.; A. C. P. Evaldt, S. Giradi Bauermann \& G. Leite de Lima. 2014. Diversidade de grãos de pólen e esporos dos Campos do sul do Brasil: descrições morfológicas e implicações paleoecológicas. Iheringia, Serie Botanica 69 (1): 107-132.

Sáenz Laín, C. 2004. Glosario de términos palinológicos. Lazaroa 25: 93-112.

Salgado, C. R. \& S. M. Pire. 1998. Análisis polínico de mieles del Noroeste de la provincia de Corrientes (Argentina). Darwiniana 36 (1-4): 87-93.

Stevens, P. F. 2001. Angiosperm Phylogeny Website. Versión 14 Julio 2017. Disponible en http://www.mobot.org/MOBOT/ research/APweb/ [Accessed February 2020]. 